\title{
PENGARUH VARIASI SUHU AKTIVASI FISIKA TERHADAP SIFAT FISIS DAN ELEKTROKIMIA ELEKTRODA KARBON SUPERKAPASITOR DARI LIMBAH KULIT PISANG
}

\author{
E. Taer ${ }^{1, a)}$, S. D. Hartati ${ }^{1, b)}$, Sugianto $^{1}$, R. Taslim² \\ 1Jurusan Fisika FMIPA Universitas Riau, Jl. HR. Soebrantas KM 12,5 Simpang Baru, Pekanbaru 28293 \\ 2Jurusan Teknik Industri Universitas Islam Negeri Sultan Syarif Kasim, Pekanbaru 28293 \\ Email: ${ }^{\text {a) }}$ erman_taer@yahoo.com, ${ }^{\text {b) }}$ sitihartati16@yahoo.com
}

\begin{abstract}
Abstrak
Pengaruh variasi suhu aktivasi fisika terhadap sifat fisis dan elektrokimia Elektroda Karbon Superkapasitor (EKS) dari limbah kulit pisang telah dianalisa. Sifat fisis yang dianalisa meliputi, panjang, lebar, tebal dan densitas, sedangkan sifat elektrokimia dilakukan pada nilai kapasitansi spesifik. Pembuatan EKS ini diawali dengan proses penggilingan, pencetakan yang berukuran $12 \mathrm{~cm} \mathrm{x}$ $10 \mathrm{~cm}$, pengeringan pada suhu $150^{\circ} \mathrm{C}$ dan kemudian dipotong menjadi ukuran yang lebih kecil dengan dimensi $3 \mathrm{~cm}$ x $3 \mathrm{~cm}$. Potongan yang lebih kecil ini dikarbonisasi pada suhu $600^{\circ} \mathrm{C}$ dalam lingkungan gas $\mathrm{N}_{2}$ diikuti dengan aktivasi fisika menggunakan gas $\mathrm{CO}_{2}$ untuk mendapatkan EKS. Pengukuran sifat fisis EKS seperti massa, panjang, lebar, dan ketebalan dilakukan untuk mendapatkan besaran densitas. Hasil pengukuran densitas EKS didapati menurun secara linear dengan kenaikan suhu aktivasi, nilai masing-masing sebesar $0,846 \mathrm{~g} / \mathrm{cm}^{3}, 0,766 \mathrm{~g} / \mathrm{cm}^{3}$, dan $0,740 \mathrm{~g} / \mathrm{cm}^{3}$ untuk suhu aktivasi $800^{\circ} \mathrm{C}, 850^{\circ} \mathrm{C}$ dan $900^{\circ} \mathrm{C}$. Pengukuran sel superkapasitor dilakukan dengan metode Cyclic Voltametry (CV) pada potensial kerja 0 - $500 \mathrm{mV} / \mathrm{s}$ dengan laju scan $1 \mathrm{mV} / \mathrm{s}$ menggunakan elektrolit $\mathrm{H}_{2} \mathrm{SO}_{4} 1 \mathrm{M}$. Nilai kapasitansi spesifik didapati berkurang dengan peningkatan suhu aktivasi. Kapasitansi spesifik masingmasing sampel EKS adalah sebesar 55,2 F/g, 35,9 F/g, 10,8 F/g untuk masing-masing suhu aktivasi $800^{\circ} \mathrm{C}, 850^{\circ} \mathrm{C}$ dan $900^{\circ} \mathrm{C}$.
\end{abstract}

Kata kunci: Kulit pisang, elektroda karbon superkapasitor, densitas, kapasitansi spesifik

\begin{abstract}
The effects of temperature variation on the physical activation to the physical and electrochemical properties of Carbon Electrodes Supercapacitor (CES) from banana peels waste has been analyzed. The physical characteristic such as length, width, thickness and density has been analyzed, while the electrochemical properties was subjected on specific capacitance values. The production of CES was begun by the milling, the printing with a size of $12 \mathrm{~cm} \mathrm{x} 10 \mathrm{~cm}$, drying at a temperature of $150^{\circ} \mathrm{C}$ and then cutting into smaller sizes with a dimensions of $3 \mathrm{~cm} \times 3 \mathrm{~cm}$. These smaller pieces were carbonized at a temperature of $600^{\circ} \mathrm{C}$ in $\mathrm{N}_{2}$ gas atmosphere and followed by a physical activation using $\mathrm{CO}_{2}$ gas to get CES. The physical properties of CES such as mass, length, width, and thickness were made to get the amount of density. The density of the CES were found decreases in linearly with the increasing of the activation temperature, the density value was $0.846 \mathrm{~g} / \mathrm{cm} 3,0.766 \mathrm{~g} / \mathrm{cm} 3$ and $0.740 \mathrm{~g} / \mathrm{cm} 3$ for the activation temperature of $800^{\circ} \mathrm{C}, 850^{\circ} \mathrm{C}$ and $900^{\circ} \mathrm{C}$, respectively.Supercapacitor cells were measured by Cyclic Voltametry $(\mathrm{CV})$ method in the work potential of $0-500 \mathrm{mV} / \mathrm{s}$ with a scan rate of $1 \mathrm{mV} / \mathrm{s}$ using a $1 \mathrm{M} \mathrm{H}_{2} \mathrm{SO}_{4}$ electrolyte. The Specific capacitance value found decreased with an increasing the
\end{abstract}


activation temperature.Specific capacitance of each sample CES were $55.2 \mathrm{~F} / \mathrm{g}, 35.9 \mathrm{~F} / \mathrm{g}, 10.8 \mathrm{~F} / \mathrm{g}$ for each activation temperature of $800^{\circ} \mathrm{C}, 850^{\circ} \mathrm{C}$ and $900^{\circ} \mathrm{C}$.

Keywords: Banana peels, carbon electrodes supercapacitor, density, specific capacitance

\section{PENDAHULUAN}

Superkapasitor merupakan salah satu produk inovasi teknologi terbarukan yang mampu menyimpan energi dalam jumlah yang besar. Kemampuan penyimpanan energi pada superkapasitor dipengaruhi oleh ukuran pori dan bentuk partikel elektroda karbon [1]. Superkapasitor terdiri dari elektroda, elektrolit, pemisah (separator) dan pengumpul arus.

Elektroda karbon aktif dapat dibuat dari salah satu bahan biomassa yaitu limbah kulit pisang. Penelitian sebelumnya menyatakan bahwa "Elektroda Carbon Paper (ECP)dari limbah kulit pisang memiliki dimensi yang lebih besar dari elektroda karbon lainnya sehingga dapat menghasilkan jumlah karbon dan nilai kapasitansi yang lebih besar pula"[2].

Pembuatan ECP ada dua tahap, yaitu karbonisasi dan aktivasi [3]. Pada penelitian ini ECP diaktivasi dengan variasi temperatur yaitu, $800^{\circ} \mathrm{C}, 850^{\circ} \mathrm{C}$, dan $900^{\circ} \mathrm{C}$. Proses aktivasi dilakukan dengan menggunakan gas $\mathrm{CO}_{2}$ yang dialirkan kedalam furnace. Pemilihan gas $\mathrm{CO}_{2}$ dikarenakan penggunaan gas $\mathrm{CO}_{2}$ jauh lebih ekonomis dibandingkan menggunakan aktivasi kimia seperti, $\mathrm{NaOH}$ dan $\mathrm{KOH}$. Selain itu, reaksi yang terjadi dengan penggunaan aktivator $\mathrm{CO}_{2}$ merupakan reaksi endoterm sehingga lebih mudah dikontrol, bersih, dan cocok untuk penelitian berskala laboratorium [4]. ECP variasi temperatur aktivasi $\mathrm{CO}_{2}$ dilakukan untuk menentukan suhu pengaktifan terbaik serta menghasilkan ECP dengan kapasitansi spesifik yang tinggi.

\section{METODE PENELITIAN}

\section{Pembuatan Sampel}

Bahan utama yang digunakan pada penelitian ini adalah limbah kulit pisang. Pembuatan ECPdari limbah kulit pisangini merujuk pada penelitian sebelumnya yaitu pada laporan [1].Bubur kulit pisang yang sudah dihaluskan dimasukkan kedalam cetakan ukuran $12 \mathrm{~cm} \times 10 \mathrm{~cm}$. Sampel tersebut ditimbang terlebih dahulu dengan massa 150 gr setiap satu cetakan kemudian dioven pada temperatur $150^{\circ} \mathrm{C}$ selama $3 \mathrm{jam}$. Selanjutnya sampel dilepas dari cetakan dan dipotong menjadi ukuran yang lebih kecil dengan dimensi $3 \mathrm{~cm}$ x $3 \mathrm{~cm}$ serta dikeringkan kembali pada temperatur $110^{\circ} \mathrm{C}$ sampai massa konstan.

Potongan yang lebih kecil ini kemudian dikarbonisasi menggunakan furnace yang dialiri gas $\mathrm{N}_{2}$ pada suhu $600^{\circ} \mathrm{C}$ selama \pm 8 jam. Profil pemanasan dibuat bertingkat pada temperatur 285 yang ditahan selama 1 jam. Selanjutnya, ECP diaktivasi dengan menggunakan gas $\mathrm{CO}_{2}$ yang dialirkan kedalam furnace dengan variasi temperatur yaitu, $800^{\circ} \mathrm{C}, 850^{\circ} \mathrm{C}$, dan $900^{\circ} \mathrm{C}$ selama 2 jam. ECP yang sudah diaktivasi dipoles menggunakan kertas pasir P240 dan P1200. Proses selanjutnya adalah pencucian menggunakan air suling sehingga $\mathrm{pH}$ air cucian menjadi netral. ECP yang telah netral selanjutnya dikeringkan menggunakan oven pada suhu $110^{\circ} \mathrm{C}$ selama \pm 24 jam. ECP selanjutnya dibuat sel superkapasitor menggunakan beberapa bahan, yaitu teflon, pengumpul arus (Stainles Stell), separator (membran kulit telur itik), elektroda (dari kulit pisang), dan elektrolit $\left(\mathrm{H}_{2} \mathrm{SO}_{4}\right)$.

\section{Pengukuran} $(\mathrm{CV})$.

Pengukuran yang dilakukan adalah pengukuran densitas dan pengukuran Cyclic Voltammetry

\section{Pengukuran Densitas}

Untuk menentukan densitas sampel, ECP yang berbentuk lembaran diukur panjang, lebar, dan tebalnya menggunakan jangka sorong. Kemudian sampel ditimbang massanya dengan timbangan digital, sehingga dari data yang diperoleh dapat dihitung nilai densitas dari masing - masing sampel. 


\section{Pengukuran Cyclic Voltammetry}

Pengukuran CV dilakukan untuk mengetahui nilai kapasitansi dari sel superkapasitor dengan menggunakan alat Physic CV UR Rad-Er 5841, pada potensial kerja 0 - $500 \mathrm{mV} / \mathrm{s}$ dan laju scan $1 \mathrm{mV} / \mathrm{s}$. Kapasitansi spesifik (Csp) dari pengukuran CV dapat dihitung menggunakan persamaan berikut [5] :

$$
C_{s p}=\frac{2\left\lfloor\left(I_{c}-\left(-I_{d}\right) / 2\right\rfloor\right.}{s \times m}
$$

dimana

$C_{s p}=$ Kapasitansi spesifik $(\mathrm{F} / \mathrm{g})$

$I_{c}=$ Arus charge $(\mathrm{A})$

$I_{\text {d }}=$ Arus discharge $(\mathrm{A})$

$s \quad=$ Laju scan $(\mathrm{mV} / \mathrm{s})$

$\mathrm{m}=\operatorname{Massa}(\mathrm{g})$

\section{HASIL DAN PEMBAHASAN}

\section{Densitas}

Hasil pengukuran densitas saat pra - karbonisasi, karbonisasi dan aktivasi fisika dari ketiga sampel ECP limbah kulit pisang dapat dilihat pada Gambar 1.

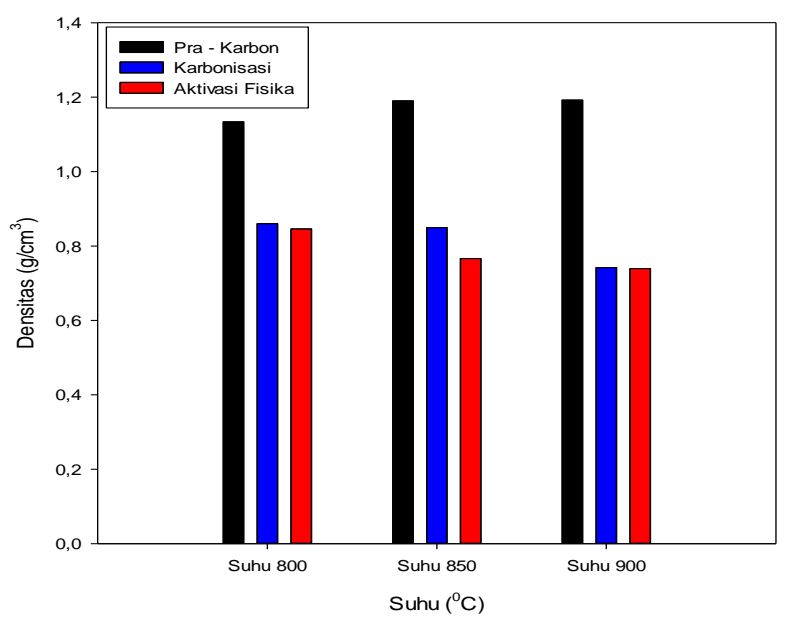

Gambar 1. Grafik perubahan densitas ECP.

Gambar 1 memperlihatkan bahwa ECP memiliki densitas yang berbeda untuk masing-masing suhu. Densitas ECP setelah proses aktivasi fisika. mengalami penurunan secara linier. Penurunan densitas yang linear ini diakibatkan karena selama proses aktivasi fisika berlangsung, terjadi pengikisan karbon untuk pembentukkan pori-pori baru pada permukaan karbon. Semakin tinggi temperatur aktivasi fisika yang digunakan maka akan menghasilkan penurunan densitas yang semakin tinggi pula. Temperatur yang tinggi akan menyebabkan karbon terdekomposisi. Proses dekomposisi menghasilkan senyawa yang mudah menguap dan terlepas dari unsur karbon, sehingga kandungan karbon dalam sampel cukup tinggi. Hal ini terlihat bahwa setiap kenaikan temperatur, maka semakin banyak reaksi antara karbon dan gas $\mathrm{CO}_{2}$ yang terjadi sehingga penurunan densitasnya akan semakin besar.

Hasil pengukuran CV Elektroda Karbon Superkapasitor (EKS) dari limbah kulit pisang suhu $800^{\circ} \mathrm{C}, 850^{\circ} \mathrm{C}$, dan $900^{\circ} \mathrm{C}$ pada laju scan $1 \mathrm{mV} / \mathrm{s}$ dengan rentang tegangan $0-0,5$ volt berupa kurva 
hubungan antara rapat arus dan tegangan superkapasitor. Pengukuran CV dilakukan menggunakan alat Physics CV UR Rad-Er 5841.

Besarnya arus charge (pengisian) dan arus discharge (pengosongan) pada saat pengukuran CV mempengaruhi bentuk kurva yang dihasilkan. Semakin lebar kurva maka akan semakin besar arus charge dan discharge yang menandakan semakin besarnya nilai kapasitansi yang dihasilkan seperti yang ditunjukkan pada Gambar 2.

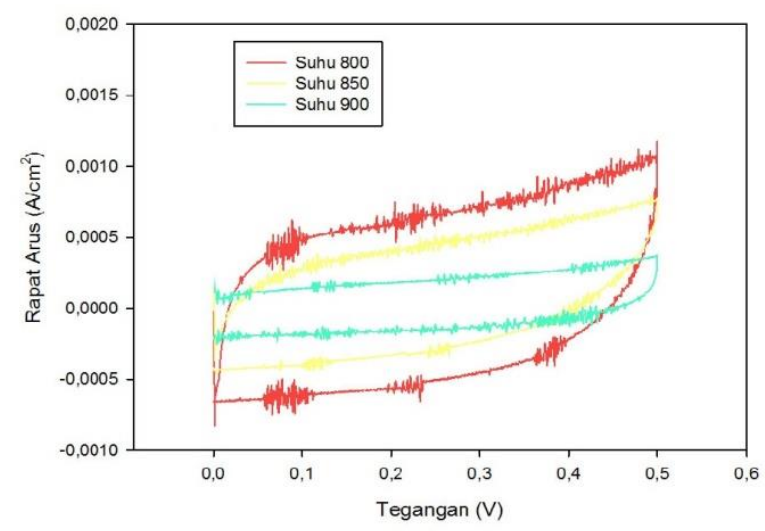

Gambar 2. Kurva cyclic voltammogram pada laju scan $1 \mathrm{mV} / \mathrm{s}$.

Secara terperinci, perhitungan nilai kapasitansi spesifik masing - masing EKS dapat dilihat pada Tabel 2.

\section{Cyclic Voltammetry}

Tabel 2. Data hasil pengukuran kapasitansi spesifik EKS dari limbah kulit pisang.

\begin{tabular}{|c|c|c|c|c|c|c|}
\hline NO & $\begin{array}{c}\text { Suhu Aktivasi } \\
\left({ }^{0} \mathrm{C}\right)\end{array}$ & $\begin{array}{c}\mathrm{S} \\
(\mathrm{V} / \mathrm{s})\end{array}$ & $\begin{array}{c}\mathrm{m}_{\text {rata-rata }} \\
(\mathrm{g})\end{array}$ & $\begin{array}{c}\text { Ic } \\
(\mathrm{A})\end{array}$ & $\begin{array}{c}\text { Id } \\
(\mathrm{A})\end{array}$ & $\begin{array}{c}\text { Csp } \\
(\mathrm{F} / \mathrm{g})\end{array}$ \\
\hline 1 & 800 & 0,001 & 0,022 & 0,000712 & $-0,000503$ & 55,2 \\
\hline 2 & 850 & 0,001 & 0,022 & 0,000465 & $-0,000326$ & 35,9 \\
\hline 3 & 900 & 0,001 & 0,021 & 0,000121 & $-0,000100$ & 10,8 \\
\hline
\end{tabular}

Dari data yang ditampilkan pada Tabel 2 diperoleh bahwa semakin tinggi suhu aktivasi fisika yang digunakan maka EKS dari limbah kulit pisang akan memiliki nilai kapasitansi spesifik yang semakin rendah. Dengan kata lain, suhu aktivasi fisika berbanding terbalik dengan nilai kapasitansi spesifik. Nilai kapasitansi spesifik terbesar dimiliki oleh EKS suhu aktivasi 8000C yaitu 55,2 F/g dan nilai kapasitansi spesifik terendah dimiliki oleh EKS suhu aktivasi 9000C yaitu 10,8 F/g. Seperti yang ditunjukkan pada Gambar 3.

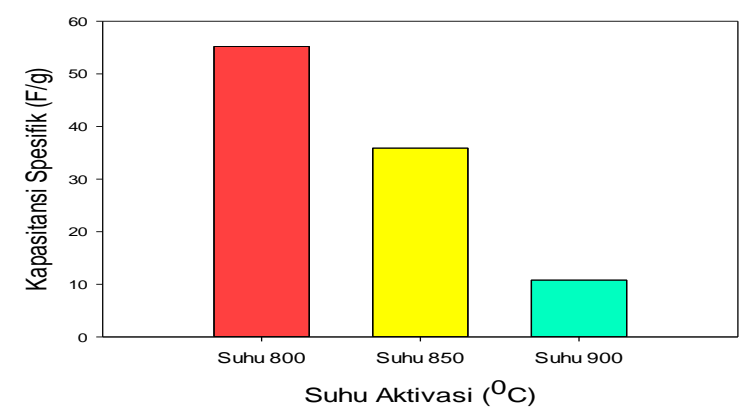

Gambar 3. Grafik nilai kapasitansi spesifik EKS pada laju scan 1mV/s. 


\section{KESIMPULAN}

Berdasarkan hasil penelitian dan analisa data yang telah dilakukan maka didapatkan kesimpulan sebagai berikut :

Efek variasi suhu aktivasi fisika menggunakan gas CO2 menyebabkan nilai densitas dan kapasitansi yang berbeda. Semakin tinggi suhu aktivasi fisika yang digunakan maka akan menghasilkan penurunan nilai densitas serta kapasitansi secara linear.

Nilai densitas dan kapasitansi maksimum sebesar $0,846 \mathrm{~g} / \mathrm{cm} 3$ dan 55,2 F/g diperoleh pada suhu 8000C, sedangkan pada suhu 9000C memperoleh nilai densitas dan kapasitansi minimum sebesar $0,740 \mathrm{~g} / \mathrm{cm} 3$ dan $10,8 \mathrm{~F} / \mathrm{g}$.

\section{UCAPAN TERIMAKASIH}

Penulis mengucapkan terima kasih kepada penyokong dana penelitian yaitu Proyek HIKOM tahun 2016 yang diberikan kepada Peneliti utama Dr. Erman Taer, M.Si.

\section{DAFTAR ACUAN}

[1] E. Taer., M. Deraman., I.A. Thalib., A. Awitdrus., S.A. Hasmi., A.A. Umar. Preparation of a Highly Prous Binderless Activated Carbon Monolith from Rubber Wood Saw Dust by a Multi Step Activation Process for Application in Supercapacitors. Int. Journal Electrochem. Sci., 6 (2011), pp. 3301 - 3315.

[2] E. Taer., Desmawati., Sugianto., R. Taslim. 2015. Pembuatan dan Karakterisasi Sifat Fisika Green Karbon Paper Tanpa Menggunakan Perekat Menggunakan Limbah Biomassa. Jurnal Seminar Nasional Fisika 15:1-5.

[3] R. Kötz., and M. Bärtschi. 2002. Hy. Power-A Fuel Cell Car Boosted with Supercapacitors. The 12th International Seminar on Double Layer Capacitors and Similar Energy Storage Devices. DeerfieldBeach, USA.

[4] T. Zhang., W.P. Walawender., L.T. Fan., M. Fan., D. Daugaard., R.C. Brown. Preparation of Activated Carbon from Forest and Agricultural Residues through CO2 Activation,Chemical Engineering Journal. 105 (2004), pp. 53-59.

[5] D. Kalpana., S.H. Cho., S.B. Lee., Y.S. Lee., R. Misra., N.G. Renganathan. Recycled Waste Paper-A New Source Of Raw Material For Electric Double-Layer Capacitors. Journal of Power Sources 190(2009), pp. 587-591. 
